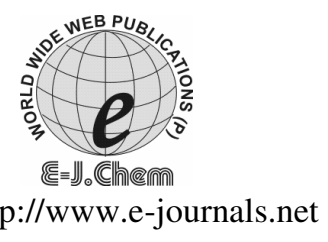

ISSN: 0973-4945; CODEN ECJHAO

E-Journal of Chemistry

http://www.e-journals.net 2010, 7(2), 655-664

\title{
Synthesis of Thienopyrimidines and their Antipsychotic Activity
}

\author{
CHANCHAL SHARMA*, SWAPNIL YERANDE, \\ RAJASHREE CHAVAN and A. V. BHOSALE
}

\author{
Department of Pharmaceutical Chemistry, \\ Poona District Education Association's Seth Govind Raghunath \\ Sable College of Pharmacy, Saswad, Dist. Pune, Maharashtra-412 301, India. \\ Chanchaljangid84@gmail.com
}

Received 12 August 2009; Accepted 5 October 2009

\begin{abstract}
A series of thienopyrimidines and related heterocycles were synthesized by refluxing related imidoyl chloride with primary and secondary amines under microwave irradiation and classical heating. The imidoyl chlorides were synthesized from corresponding cyclic imides with phosphorus oxychlorides under microwave irradiation and classical heating. The structures of the compounds were confirmed by FT-IR, NMR. The synthesized compounds were screened for anti psychotic activity.
\end{abstract}

Keywords: Gewald product, Thienopyrimidine, Imidoyl chloride, Antipsychotic activity.

\section{Introduction}

Activation of central dopaminergic systems is generally considered to be the most important factor in the etiology of schizophrenia ${ }^{1,2}$. Several dopamine and serotonin antagonists (atypical antipsychotics) such as clozapine, olanzapine, risperidone, quietapine, sertindole, seroquel have been found to exhibit effective atypical antipsychotic activity. These compounds still are associated with some extrapyramidal side effects ${ }^{3}$. Literature reports that the compounds synthesized by removal of one of the benzene ring of clozapine were having same affinity on dopaminergic receptors to that of clozapine with minimization of its extrapyramidal side effects ${ }^{4}$. Clozapine, olanzapine, seroquel and other atypical antipsychotics have greater affinity for serotonin receptor than dopamine receptors ${ }^{5,6}$. An attempt has been made in direction of synthesizing olanzapine analogues by removal of one of the benzene rings of it and replacement of its seven membered diazepine ring by six membered pyrimidine ring for the sake of improving its dopamine selectivity and minimization of extrapyramidal side effects. 


\section{Experimental}

Melting points were determined in open capillary on Veego (model: VMP-D) electronic apparatus and were uncorrected. Purity of the compounds were verified by running TLC, using precoated plates. The IR spectra of the compounds were recorded on Shimadzu 8400-S FT-IR Spectrophotometer using $\mathrm{KBr}\left(\mathrm{cm}^{-1}\right)$. ${ }^{1} \mathrm{H}$ NMR Spectra was recorded in $\mathrm{CDCl}_{3}$ using NMR VarianMercury $300 \mathrm{MHZ}$ spectrometer using TMS as internal standard (chemical shifts in $\delta \mathrm{ppm}$ ).

Synthetic of 2-amino-5-substituted-thiophene-3-carboxylate (2a-c)

The compounds (2a-c) were synthesized by Gewald reaction ${ }^{7,8}$. The eqimolar quantities of ethylcyanoacetate, aldehyde / ketone (propionaldehyde for $\mathbf{2 a}$, butyraldehyde for $\mathbf{2 b}$, cyclohexanone for $\mathbf{2 c}$, sulphur and TEA for $\mathbf{2} \mathbf{a} / \mathbf{b}$ ) or DEA (for $\mathbf{2 c}$ ), in DMF (for $\mathbf{2} \mathbf{a}, \mathbf{b}$ ) ethanol (for $\mathbf{2 c}$ ) were taken. The reaction mixture was kept for $24 \mathrm{~h}(24 \mathrm{~h}$ for $\mathbf{2 a}, 20 \mathrm{~h}$. for $\mathbf{2 b}, 1 \mathrm{~h}$. for 2c) with constant stirring. Then it was refluxed in a microwave for $20 \mathrm{~min}$. at power level 4 . The resulting solution of $\mathbf{2 a}, \mathbf{2} \mathbf{b}$ was added in equal volume of ice-cold water, and extracted with methylene chloride. Organic layer was washed 2-3 times with $0.1 \mathrm{M} \mathrm{HCl}$ and then with brine solution. Organic layer was separated and dried over anhydrous $\mathrm{Na}_{2} \mathrm{SO}_{4}$. For $2 \mathrm{c}$ the solid obtained was filtered and washed with water and recrystalized by using $\mathrm{CH}_{3} \mathrm{OH}$.

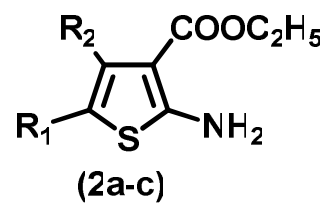

Ethyl 2-amino-5-methylthiophene-3-carboxylate (2a)

IR(KBr, $\left.\mathbf{c m}^{-1}\right)$ : 3402.54, $3309.96(\mathrm{~N}-\mathrm{H}), 3174.93,3072.71(=\mathrm{C}-\mathrm{H}), 2993.62,2914.93(-\mathrm{C}-\mathrm{H})$,

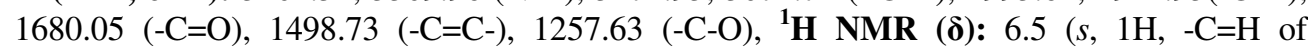
thiophene), $5.5\left(s, 2 \mathrm{H},-\mathrm{NH}_{2}\right), 4.2\left(q, 2 \mathrm{H},-\mathrm{CH}_{2}-\mathrm{CH}_{3}\right), 2.2\left(s, 3 \mathrm{H},-\mathrm{CH}_{3}\right), 1.3\left(t, 3 \mathrm{H},-\mathrm{CH}_{2}-\mathrm{CH}_{3}\right)$

Ethyl 2-amino-5-ethylthiophene-3-carboxylate $(\mathbf{2 b})$

IR(KBr, $\left.\mathbf{c m}^{-1}\right): 3406.4,3308(-\mathrm{N}-\mathrm{H}), 3169.15(\mathrm{Ar}=\mathrm{C}-\mathrm{H}), 2966.62,2901.04(-\mathrm{C}-\mathrm{H}), 1658.84$ $(-\mathrm{C}=\mathrm{O}), 1593.25(-\mathrm{C}=\mathrm{C}-), 1255.70(-\mathrm{C}-\mathrm{O}),{ }^{1} \mathbf{H}$ NMR $(\boldsymbol{\delta}): 6.6(s, 1 \mathrm{H},-\mathrm{C}=\mathrm{H}$ of thiophene), $5.7\left(s, 2 \mathrm{H},-\mathrm{NH}_{2}\right), 4.2\left(q, 2 \mathrm{H},-\mathrm{COO}-\mathrm{CH}_{2}-\mathrm{CH}_{3}\right), 2.6\left(q, 2 \mathrm{H},-\mathrm{CH}_{2}-\mathrm{CH}_{3}\right), 1.3(t, 3 \mathrm{H},-\mathrm{COO}-$ $\left.\mathrm{CH}_{2}-\mathrm{CH}_{3}\right), 1.4\left(t, 3 \mathrm{H},-\mathrm{CH}_{2}-\mathrm{CH}_{3}\right)$

Ethyl 2-amino-4, 5, 6, 7 tetrahydrobenzo[b]thiophene-3-carboxylate (2c)

IR(KBr, $\left.\mathbf{c m}^{-1}\right):$ 3408.33, $3302.24(-\mathrm{N}-\mathrm{H}), 3076.56(=\mathrm{C}-\mathrm{H}), 2939.62(-\mathrm{C}-\mathrm{H}), 1647.26$ $(-\mathrm{C}=\mathrm{O}), 1597.11$ (-C=C-), $1278.84(-\mathrm{C}-\mathrm{O}),{ }^{1} \mathbf{H}$ NMR $(\boldsymbol{\delta}): 5.9\left(s, 2 \mathrm{H},-\mathrm{NH}_{2}\right), 4.2(q, 2 \mathrm{H},-$ $\left.\mathrm{CH}_{2}-\mathrm{CH}_{3}\right), 2.7(s, 2 \mathrm{H}$, cyclohexane ring), $2.6(s, 2 \mathrm{H}$, cyclohexane ring), $1.7(s, 4 \mathrm{H}$, cyclohexane ring), $1.3\left(t, 3 \mathrm{H},-\mathrm{CH}_{2}-\mathrm{CH}_{3}\right)$

Synthesis of thienopyrimidines $(3 a-3 c)$

Compound 3a-c were synthesized ${ }^{9-11}$ by refluxing the compounds (2a-c) with excess of formamide at $<200{ }^{\circ} \mathrm{C}$ for $7 \mathrm{~h}$ or in microwave for $1 \mathrm{~h}$ at power level 5 . Reaction mixtures were kept overnight and the solid obtained was filtered and recrystalized with methanol.<smiles>[R]c1sc2nc[nH]c(=O)c2c1[R]</smiles>

(3a-c) 
6-Methylthieno[2,3-d]pyrimidin-4(3H)-one (3a)

IR(KBr, cm $\left.{ }^{-1}\right): 3234.73(-\mathrm{N}-\mathrm{H}), 3153.72(=\mathrm{C}-\mathrm{H}), 2998.78(-\mathrm{C}-\mathrm{H}), 1693.58(-\mathrm{C}=\mathrm{O}), 1641.40$ $(-\mathrm{C}=\mathrm{N}), 1481.38(-\mathrm{C}=\mathrm{C}-), 1141.90(-\mathrm{C}-\mathrm{N}),{ }^{1} \mathbf{H}$ NMR $(\boldsymbol{\delta}): 11.65(s, 1 \mathrm{H},-\mathrm{OH}), 8.0(s, 1 \mathrm{H}$, $=\mathrm{C}-\mathrm{H}$ of pyrimidine $), 7.1(s, 1 \mathrm{H},=\mathrm{C}-\mathrm{H}$ of thiophene ring $), 2.5\left(s, 3 \mathrm{H},-\mathrm{CH}_{3}\right)$.

6-Ethylthieno[2,3-d]pyrimidin-4(3H)-one (3b)

IR(KBr, cm $\left.{ }^{-1}\right): 3294.52(-\mathrm{N}-\mathrm{H}), 2974.33,2883.68(-\mathrm{C}-\mathrm{H}), 1666.56(-\mathrm{C}=\mathrm{O}), 1583.61(-\mathrm{C}=\mathrm{N}-)$, $1541.18(-\mathrm{C}=\mathrm{C}-)$

5,6,7,8-Tetrahydrobenzthieno[2,3-d]pyrimidin-4(3H)-one (3c)

IR(KBr, $\left.\mathbf{c m}^{-1}\right)$ : 3306.1 (-N-H), 3095.85 (=C-H), 2943.47 (-C-H), 1654.98 (-C=O), 1593.25 $(-\mathrm{C}=\mathrm{C}-), 1138.04(-\mathrm{C}-\mathrm{N})$<smiles>[R]c1sc2ncnc(Cl)c2c1[R]</smiles>

(4a-c)

Synthesis of 4-chloro-5,6-disubstitutedthieno[2,3-d]pyrimidine $(\mathbf{4 a - 4 c})^{12-14}$

Compound 4a-c were synthesized by refluxing $0.01 \mathrm{~mol}$ of $\mathbf{2 a}$ for $\mathbf{3 a}, \mathbf{2 b}$ for $\mathbf{3 b}, \mathbf{2} \mathbf{c}$ for $\mathbf{3 c}$, with $5 \mathrm{~mL}$ of $\mathrm{POCl}_{3}$ for $3 \mathrm{hrs}$. $\mathrm{POCl}_{3}$ was quenched by adding equal quantity of ice in respected solution and then extracted it with diethylether.

4-Chloro-6-methylthieno[2,3-d]pyrimidine (4a)

IR(KBr, $\left.\mathbf{c m}^{-1}\right): 3090.07$ (=C-H), $1631.83(-\mathrm{C}=\mathrm{N}), 1473.83$ (-C=C), 842.92 (-C-Cl)

4-chloro-6-ethylthieno[2,3-d]pyrimidine (4b)

IR(KBr, $\left.\mathbf{c m}^{-1}\right)$ : 3088.13, 3039.91 (=C-H), 2972.40, $2933.82(-\mathrm{C}-\mathrm{H}), 1543.10(-\mathrm{C}=\mathrm{N})$, $831.34(-\mathrm{C}-\mathrm{Cl})$

\section{4-Chloro-5,6,7,8-tetrahydrobenzthieno[2,3-d]-pyrimidine (4c)}

IR(KBr, $\left.\mathbf{c m}^{-1}\right): 3157.57$ (=C-H), 2937.68, $2848.96(-\mathrm{C}-\mathrm{H}), 1662.69(-\mathrm{C}=\mathrm{N}), 1595.18$ $(-\mathrm{C}=\mathrm{C}-), 835.20$ (-C-Cl).

\section{Synthesis of thienopyrimidines}

The compound $\mathbf{4 a}$ and $n$-phenylpiperazine (for $\mathbf{5} \mathbf{a}_{1}$ ) or morpholine (for $\mathbf{5} \mathbf{a}_{2}$ ) in proportion of 1 : 1.5 were dissolved in dioxane and reaction mixture ${ }^{10}$ was refluxed for $3.5 \mathrm{~h}$. After cooling, equal quantity of water was added to this reaction mixture and extracted with $\mathrm{CHCl}_{3}$, purification was done by using column chromatography $\left(\mathrm{CHCl}_{3}: \mathrm{CH}_{3} \mathrm{OH}\right.$; 98.2: 0.2$)$ for $\mathbf{5} \mathbf{a}_{1}$ and $\mathrm{CHCl}_{3}$ for $\mathbf{5} \mathbf{a}_{2}$. 6-Methyl-4-(4-methylpiperazin-1-yl)thieno[2,3 d]pyrimidine $\left(5 \boldsymbol{a}_{1}\right)$

IR(KBr, $\left.\mathbf{c m}^{-1}\right): 3068.84$ (=C-H), 2926.11, $2852.81(-\mathrm{C}-\mathrm{H}), 1558.53(-\mathrm{C}=\mathrm{N}), 1437.01$ $(-\mathrm{C}=\mathrm{C}-), 1143.82(-\mathrm{C}-\mathrm{N}),{ }^{1} \mathbf{H}$ NMR $(\boldsymbol{\delta}): 8.4(\mathrm{~s}, 1 \mathrm{H},=\mathrm{C}-\mathrm{H}$ of Pyrimidine ring), $6.9(\mathrm{~s}, 1 \mathrm{H}$, $=\mathrm{C}-\mathrm{H}$ of thiophene ring), $3.8(\mathrm{~s}, 4 \mathrm{H}$, piperazine ring $), 2.5\left(\mathrm{~s}, 6 \mathrm{H}, 2-\mathrm{CH}_{3}\right.$ groups attached to thiophene and piperazine ring), 2.3 (s,4H, piperazine ring)

4-(6-Methylthieno[2,3-d]pyrimidin-4-yl)morpholine (5a $\left.\boldsymbol{a}_{2}\right)$

IR(KBr, cm $\left.{ }^{-1}\right) 3018.69$ (=C-H), $2918.39 \quad(-\mathrm{C}-\mathrm{H}), 1554.67 \quad(-\mathrm{C}=\mathrm{N}), 1498.73 \quad(-\mathrm{C}=\mathrm{C}-)$, $1257.63(-\mathrm{C}-\mathrm{N}), 1118.75$ (-C-O), ${ }^{1} \mathbf{H}$ NMR $(\boldsymbol{\delta}): 8.4(s, 1 \mathrm{H},=\mathrm{C}-\mathrm{H}$ of pyrimidine ring), 6.9 $(s, 1 \mathrm{H},=\mathrm{C}-\mathrm{H}$ of thiophene ring $), 3.8(s, 8 \mathrm{H}$, morpholine ring $), 2.5\left(s, 3 \mathrm{H},-\mathrm{CH}_{3}\right)$ 


\section{Synthesis of $\mathbf{5} \boldsymbol{a}_{3}, \mathbf{5} \boldsymbol{a}_{4}, \mathbf{5} \boldsymbol{a}_{5}, \mathbf{5} \boldsymbol{a}_{6}$}

The compound $\mathbf{4 a}$ and $n$-phenylpiperazine (for $\mathbf{5} \mathbf{a}_{3}$ ) or $o$-toluidine (for $\mathbf{5} \mathbf{a}_{\mathbf{4}}$ ) or $p$-anisidine (for $\mathbf{5} \mathbf{a}_{5}$,) or piperidine-3-carboxamide (for $\mathbf{5 a}_{\mathbf{6}}$ ) in proportion of 1: 1.5 equivalent were dissolved in DMF and reaction mixture was refluxed in microwave for $30 \mathrm{~min}$ at power level 3 (for $\mathbf{5} \mathbf{a}_{3}, 20 \mathrm{~min}$. at power level 2 for $\mathbf{5} \mathbf{a}_{4}, 30 \mathrm{~min}$. at power level 5 for $\mathbf{5} \mathbf{a}_{\mathbf{5}}, 20 \mathrm{~min}$. at power level 5 for $\mathbf{5} \mathbf{a}_{\mathbf{6}}$ ). After cooling the reaction mixture, water was added and solid was filtered and purification was done by using column chromatography (Petroleum ether: ethyl acetate 8:2) for $\mathbf{5} \mathbf{a}_{3}$ and $\mathbf{5} \mathbf{a}_{4},\left(\mathrm{CHCl}_{3}\right.$ for $\left.\mathbf{5} \mathbf{a}_{5}\right)$. Compound $\mathbf{5} \mathbf{a}_{\mathbf{6}}$ was purified by washing the crystals 2-3 times subsequently by using $\mathrm{CH}_{3} \mathrm{OH}$ and diethyl ether.

6-Methyl-4-(4-phenylpiperazin-1-yl)thieno[2,3-d]pyrimidine $\left(5 \boldsymbol{a}_{3}\right)$

IR(KBr, $\left.\mathbf{c m}^{-1}\right):$ 3063.06, $3032.20(=\mathrm{C}-\mathrm{H}), 2912.60(-\mathrm{C}-\mathrm{H}), 1556.61(-\mathrm{C}=\mathrm{N}), 1446.66$ $(-\mathrm{C}=\mathrm{C}-), 1138.04(-\mathrm{C}-\mathrm{N}),{ }^{1} \mathbf{H}$ NMR $(\boldsymbol{\delta}): 8.4(s, 1 \mathrm{H},=\mathrm{C}-\mathrm{H}$ of pyrimidine ring), 7.3 ( $m, 2 \mathrm{H}$, phenyl ring), $6.9(m, 4 \mathrm{H}$, phenyl rig), $4.0(t, 4 \mathrm{H}$, piperazine), $3.3(t, 4 \mathrm{H}$, piperazine $)$, $2.5\left(s, 3 \mathrm{H},-\mathrm{CH}_{3}\right)$

\section{6-Methyl-N-o-tolylthieno[2,3-d]pyrimidin-4-amine $\left(\mathbf{5} \boldsymbol{a}_{4}\right)$}

IR(KBr, $\left.\mathbf{c m}^{-1}\right): 3248.23(-\mathrm{N}-\mathrm{H}), 3070.77(=\mathrm{C}-\mathrm{H}), 2918.39(-\mathrm{C}-\mathrm{H}), 1575.89(-\mathrm{C}=\mathrm{N})$,

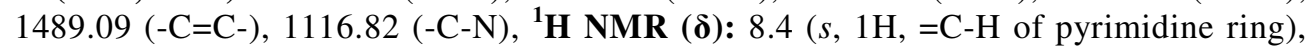
$7.6(d, 1 \mathrm{H}$, phenyl ring), $7.2(\mathrm{~m}, 3 \mathrm{H}$, phenyl ring $), 6.8(s, 1 \mathrm{H},-\mathrm{NH}-), 6.4(s, 1 \mathrm{H},=\mathrm{C}-\mathrm{H}$ of thiophene ring), $2.5\left(s, 3 \mathrm{H},-\mathrm{CH}_{3}\right.$ attached to thiophene ring), $2.3\left(\mathrm{~s}, 3 \mathrm{H},-\mathrm{CH}_{3}\right.$ of $o$-toluidine)

\section{$N$-(4-Methoxyphenyl)-6-methylthieno[2,3 d]pyrimidin-4-amine $\left(\mathbf{5} \boldsymbol{a}_{5}\right)$}

IR(KBr, cm $\left.{ }^{-1}\right): 3257.87(-\mathrm{N}-\mathrm{H}), 3090.065,3057.274$ (=C-H), 2997.47, 2968.54 (-C-H),

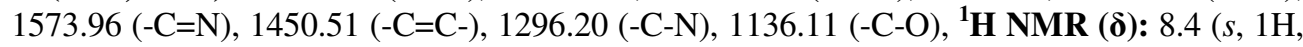
$=\mathrm{C}-\mathrm{H}$ of pyrimidine ring), $7.4(d, 2 \mathrm{H}$, phenyl ring $), 7.1(s, 1 \mathrm{H},-\mathrm{NH}-), 6.9(d, 2 \mathrm{H}$, phenyl ring $)$, $6.6\left(s, 1 \mathrm{H},=\mathrm{C}-\mathrm{H}\right.$ of thiophene ring), $3.8\left(s, 3 \mathrm{H},-\mathrm{OCH}_{3}\right), 2.5\left(s, 3 \mathrm{H},-\mathrm{CH}_{3}\right)$.

\section{1-(6-Methylthieno[2,3-d]pyrimidin-4-yl)piperidine-3-carboxamide (5 $\left.\boldsymbol{a}_{6}\right)$}

IR(KBr, $\left.\mathbf{c m}^{-1}\right): 3346.61 ， 3201.94(-\mathrm{N}-\mathrm{H}), \quad 2941.54,2860.53(-\mathrm{C}-\mathrm{H}), 1662.69(-\mathrm{C}=\mathrm{O})$, $1556.61(-\mathrm{C}=\mathrm{N}), 1498.74(-\mathrm{C}=\mathrm{C}-), 1267.27(-\mathrm{C}-\mathrm{N}),{ }^{1} \mathbf{H}$ NMR $(\boldsymbol{\delta}): 8.4(s, 1 \mathrm{H},=\mathrm{C}-\mathrm{H}$ of pyrimidine ring), $6.9\left(d, 2 \mathrm{H},-\mathrm{CONH}_{2}\right), 5.7(s, 1 \mathrm{H},=\mathrm{C}-\mathrm{H}$ of thiophene ring $), 4.2(m, 2 \mathrm{H}$, piperidine-3-carboxamide), $3.8(\mathrm{~m}, 1 \mathrm{H}$, piperidine-3-carboxamide $), 3.5(\mathrm{~m}, 1 \mathrm{H}$, piperidine-3carboxamide $), 2.6\left(m, 4 \mathrm{H},-\mathrm{CH}_{3}\right.$ of thiophene ring, $1 \mathrm{H}$ of $\left.-\mathrm{CH}-\mathrm{CONH}_{2}\right), 2.1(\mathrm{~m}, 2 \mathrm{H}$, piperidine-3-carboxamide ), 1.9 ( $m, 2 \mathrm{H}$, piperidine-3-carboxamide).

\section{Synthesis of $\mathbf{5} \boldsymbol{b}_{1}, \mathbf{5} \boldsymbol{b}_{2}$}

The compound $\mathbf{4 b}$ and $n$-methylpiperazine (for $\mathbf{5} \mathbf{b}_{\mathbf{1}}$ ) or morpholine (for $\mathbf{5 b}_{\mathbf{2}}$ ) in proportion of 1: 1.5 were dissolved in dioxane and reaction mixture was refluxed for 3.5 h. After cooling, equal quantity of water was added to this reaction mixture and extracted with $\mathrm{CHCl}_{3}$. Purification was done by using column chromatography $\left(\mathrm{CHCl}_{3}\right.$ : $\mathrm{CH}_{3} \mathrm{OH}$; 98.2: 0.2) for $\mathbf{5} \mathbf{b}_{\mathbf{1}}$ and $\mathbf{5} \mathbf{b}_{\mathbf{2}}$.

\section{6-Ethyl-4-(4-methylpiperazin-1-yl)thieno[2,3-d]pyrimidine $\left(\mathbf{5 b}_{\mathbf{1}}\right)$}

IR (KBr, cm-1) : 3064.99 (=C-H), 2968.55, $2933.83(-\mathrm{C}-\mathrm{H}), 1554.68(\mathrm{C}=\mathrm{N}), 1452.45$ $(-\mathrm{C}=\mathrm{C}-), 1263.41(-\mathrm{C}-\mathrm{N}),{ }^{1} \mathbf{H}$ NMR $(\boldsymbol{\delta}): 8.4(s, 1 \mathrm{H},=\mathrm{C}-\mathrm{H}$ of pyrimidine ring), $6.9(s, 1 \mathrm{H}$, $=\mathrm{C}-\mathrm{H}$ of thiophene ring), $3.9(t, 4 \mathrm{H}$, piperazine ring $), 2.9\left(q, 2 \mathrm{H},-\mathrm{CH}_{2}-\mathrm{CH}_{3}\right), 2.6(t, 4 \mathrm{H}$, piperazine ring $), 2.4\left(s, 3 \mathrm{H},-\mathrm{CH}_{3}\right), 1.3\left(t, 3 \mathrm{H},-\mathrm{CH}_{2}-\mathrm{CH}_{3}\right)$. 


\section{4-(6-Ethylthieno[2,3-d]pyrimidin-4-yl)morpholine (5 $\left.\boldsymbol{b}_{2}\right)$}

IR (KBr, $\left.\mathbf{c m}^{-1}\right)$ : 2970.48, $2856.67(-\mathrm{C}-\mathrm{H}), 1554.68(-\mathrm{C}=\mathrm{N}), 1444.73(-\mathrm{C}=\mathrm{C}-), 1255.70(-\mathrm{C}-\mathrm{N})$, 1118.75 (-C-O), ${ }^{1} \mathbf{H}$ NMR $(\boldsymbol{\delta}): 8.4$ (s, $1 \mathrm{H},=\mathrm{C}-\mathrm{H}$ of pyrimidine ring), 6.9 (s, 1H, =C-H of thiophene ring), 3.9 (s, $8 \mathrm{H}$, morpholine ring), 2.9 (q, $\left.2 \mathrm{H},-\mathrm{CH}_{2}-\mathrm{CH}_{3}\right), 1.3\left(\mathrm{t}, 3 \mathrm{H},-\mathrm{CH}_{2}-\mathrm{CH}_{3}\right)$

Synthesis of $5 c_{2}, 5 c_{3}, 5 c_{6}$

The compound $\mathbf{4 c}$ and morpholine (for $\mathbf{5} \mathbf{c}_{2}$ ) or $n$-phenylpiperazine (for $\mathbf{5} \mathbf{c}_{3}$ ) or $o$-anisidine (for $\mathbf{5} \mathbf{c}_{\mathbf{6}}$ ) in proportion of 1: 1.5 were dissolved in DMF and reaction mixture was refluxed in microwave for $45 \mathrm{~min}$. (at power level 4 for $\mathbf{5} \mathbf{c}_{2}, 25 \mathrm{~min}$. at power level 5 for $\mathbf{5} \mathbf{c}_{3}, 45 \mathrm{~min}$. at power level 2 for $\mathbf{5} \mathbf{c}_{\mathbf{6}}$ ). After cooling, equal quantity of water was added to this reaction mixture and extracted with $\mathrm{CHCl}_{3}$. Purification was done by using column chromatography $\left(\mathrm{CHCl}_{3}\right)$ for $\mathbf{5} \mathbf{c}_{2}$, (Petroleum ether: ethyl acetate; 7.5: 2.5) for $\mathbf{5} \mathbf{c}_{3}$. Compound $\mathbf{5} \mathbf{c}_{\mathbf{6}}$ was purified by washings the compound for 2-3 times with $\mathrm{CH}_{3} \mathrm{OH}$ and diethyl ether.

4-(5,6,7,8-Tetrahydrobenzthieno[2,3-d]pyrimidin-4-yl) morpholine (5 $\left.\boldsymbol{c}_{2}\right)$

IR(KBr, $\left.\mathbf{c m}^{-1}\right): 3030.27(=\mathrm{C}-\mathrm{H}), 2937.68,2858.61(-\mathrm{C}-\mathrm{H}), 1558.54(-\mathrm{C}=\mathrm{N}), 1437.02$ $(-\mathrm{C}=\mathrm{C}-), 1255.70(-\mathrm{C}-\mathrm{N}), 1116.52(-\mathrm{C}-\mathrm{O}),{ }^{1} \mathbf{H}$ NMR $(\boldsymbol{\delta}): 8.5(\mathrm{~s}, 1 \mathrm{H},=\mathrm{C}-\mathrm{H}$ of pyrimidine ring), $3.8(t, 4 \mathrm{H}$, morpholine ring $), 3.4(t, 4 \mathrm{H}$, morpholine ring $), 2.8(\mathrm{~m}, 4 \mathrm{H}$, cyclohexane ring), 1.9 ( $m, 4 \mathrm{H}$, cyclohexane ring).

4-[4.Phenylpiperazin-1-yl]-5,6,7,8-tetrahydrobenzthieno[2,3-d]-pyrimidine $\left(\mathbf{5 c}_{3}\right)$

IR(KBr, $\left.\mathbf{c m}^{-1}\right): 3036.57$ (=C-H), 2941.54, $2839.31(-\mathrm{C}-\mathrm{H}), 1597.11(-\mathrm{C}=\mathrm{N}), 1437.01$ $(-\mathrm{C}=\mathrm{C}-), 1234.48(-\mathrm{C}-\mathrm{N}),{ }^{1} \mathbf{H}$ NMR $(\boldsymbol{\delta}): 8.5(s, 1 \mathrm{H},=\mathrm{C}-\mathrm{H}$ of pyrimidine ring), $7.3(t, 2 \mathrm{H}$, phenyl ring), $7.2(d, 2 \mathrm{H}$, phenyl ring $), 6.9(t, 1 \mathrm{H}$, phenyl ring $), 3.5(m, 4 \mathrm{H}$, piperazine ring), $3.3(m, 4 \mathrm{H}$, piperazine ring), $2.9(t, 2 \mathrm{H}$, cyclohexane ring), $2.8(t, 2 \mathrm{H}$, cyclohexane ring), 1.9 $(t, 2 \mathrm{H}$, cyclohexane ring), $1.8(t, 2 \mathrm{H}$, cyclohexane ring).

$N$-(2-Methoxyphenyl)-5,6,7,8-tetrahydrobenzthieno[2,3-d]pyrimidin-4-amine (5 $\left.\boldsymbol{c}_{6}\right)$

IR(KBr, $\left.\mathbf{c m}^{-1}\right): 3417.98(-\mathrm{N}-\mathrm{H}), 3057.27$ (=C-H), 2945.40, 2839.31 (-C-H), 1560.46

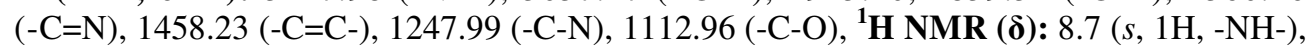
$8.5(s, 1 \mathrm{H},=\mathrm{C}-\mathrm{H}$ of pyrimidine ring $), 8.0(s, 1 \mathrm{H}$, phenyl ring $), 7.0(s, 1 \mathrm{H}$, phenyl ring $), 6.9$ $\left(s, 1 \mathrm{H}\right.$,phenyl ring), $3.9\left(s, 3 \mathrm{H},-\mathrm{OCH}_{3}\right), 3.0(s, 2 \mathrm{H}$, cyclohexane ring), $2.8(s, 2 \mathrm{H}$, cyclohexane ring), 1.9 ( $s, 4 \mathrm{H}$, cyclohexane ring).

Antipsychotic activity

The Antipsychotic activity of the synthesized compounds was evaluated by using models like spontaneous motor activity using Actophotometer, behavioral effect in mice, catalepsy test in mice.

Spontaneous motor activity using actophotometer ${ }^{15}$

The albino mice of either sex $(25-30 \mathrm{mg})$ were divided into five groups as Control, Std 2.5 (olanzapine $2.5 \mathrm{mg} / \mathrm{kg}$ ), Std 5.0 (olanzapine $5 \mathrm{mg} / \mathrm{kg}$ ), test compounds i.e. Test 10 (10 $\mathrm{mg} / \mathrm{kg})$ and Test $20(20 \mathrm{mg} / \mathrm{kg})$ of $\mathbf{5} \mathbf{a}_{\mathbf{1}}-\mathbf{5} \mathbf{c}_{\mathbf{6}}$. Each group containing 6 mice.

Control group was treated with $0.1 \%$ acacia solution p.o. and remaining groups were treated with test compounds $(10 \mathrm{mg} / \mathrm{kg}$ and $20 \mathrm{mg} / \mathrm{kg}$ p.o. by suspending test compounds in $0.1 \%$ acacia solution) and reference compound (Olanzapine $2.5 \mathrm{mg} / \mathrm{kg}$ and $5 \mathrm{mg} / \mathrm{kg}$ p.o. by suspending reference compounds in $0.1 \%$ acacia solution) respectively. Immediately after drug administration the animals were closely observed for their spontaneous locomotor activity. It was recorded by using Actophotometer. Where in interruption of beam of light 
generated a pulse which was recorded on digital counter. The locomotor count for each animal was recorded for $5 \mathrm{~min}$ at $60 \mathrm{~min}$ interval for $1 \mathrm{~h}$.

\section{Catalepsy test ${ }^{16}$}

Control group was treated with $0.1 \%$ acacia solution p.o. and remaining groups were treated with test compounds $(5 \mathrm{mg} / \mathrm{kg}$ and $10 \mathrm{mg} / \mathrm{kg}$ p.o. by suspending test compounds in $0.1 \%$ acacia solution) and reference compound (Olanzapine $2.5 \mathrm{mg} / \mathrm{kg}$ and $5 \mathrm{mg} / \mathrm{kg}$ p.o. by suspending reference compound in $0.1 \%$ acacia solution) respectively. The animals were placed individually in clear acrylic cages and allowed a minimum $30 \mathrm{~min}$ to acclimatize to the new environment. Catalepsy was assessed by positioning mice with their hind paws on the floor and their forelimbs rested on an elevated bar (set at $2.5 \mathrm{~cm}$.). The time that the paws remained on the bar was determined at $60 \mathrm{~min}$. interval for $2 \mathrm{~h}$.

\section{Behavioral effects}

The behavioral effect of test drug (20 mg/kg p.o.) was assessed by the method described by Irwin et al. ${ }^{17}$. Briefly, the effects of test compound on different behavioral paradigms in animals were scored with the use of nine degrees, that is, with a scale of $0-8$. The base score for normal signs or effects is 4 , scores below 4 are subnormal responses, those above 4 , for supernormal. The base score for abnormal signs is 0 and the maximal score is 8 . In the items mentioned below, the base score is given in parentheses. The animals were observed for $2 \mathrm{~h}$ after treatment for alertness (4), stereotypy (0), and reactivity to touch response (4), body position (4), righting reflex (0) and lacrimation (0).

\section{Results and Discussion}

Gewald products 2 were synthesized by stirring reaction mixture or by refluxing ethyl cyano acetate, aldehyde/ ketone, sulphur, solvent (DMF/Ethanol), base (TEA/DEA) in microwave. The compound $\mathbf{2}$ were refluxed with excess of formamide to synthesize thienopyrimidines 3 which on refluxing with phosphorus oxychloride give 4-chloro-5,6disubstitutedthieno[2,3-d]pyrimidine (4). Target compounds were prepared by refluxing 4 with different primary and secondary amines in the presence of DMF/dioxane in microwave (Scheme 1).

Compound 2 showed a characteristic primary amine group peak in the range 3300$3400 \mathrm{~cm}^{-1}$ and sharp carbonyl stretching vibration for ester in the range of $1640-1680.0$ $\mathrm{cm}^{-1}$. The ${ }^{1} \mathrm{H}$ NMR spectrum showed singlet of allylic proton of thiophene ring at 6.5 ppm and amine protons showed singlet at $5.5 \mathrm{ppm}$. Methylene and methyl protons of ester gave quartet and triplet at 4.2 and $1.3 \mathrm{ppm}$ respectively. Methyl protons attached to thiophene ring gave singlet at $2.2 \mathrm{ppm}$.

Compound 3 showed characteristic stretching of secondary amine with broadning of peak in the range of $3200-3300 \mathrm{~cm}^{-1}$ and sharp carbonyl stretching vibration for the cyclic imide at $1640-1690 \mathrm{~cm}^{-1}$. In ${ }^{1} \mathrm{H}$ NMR spectrum characteristics pyrimidine proton showed signal at 8.0 ppm as a singlet. Proton of thiophene ring showed singlet at $7.1 \mathrm{ppm}$. Due to keto-enol tautomerization in the structure, singlet of hydroxyl group was found at $11.65 \mathrm{ppm}$. Methyl protons attached to the thiophene ring showed singlet at $2.5 \mathrm{ppm}$.

Compound 5 showed characteristics pyrimidine proton singlet at $8.0 \mathrm{ppm}$. and singlet of proton of thiophene ring at around $7 \mathrm{ppm}$. All aromatic protons came in the region of 6.9-7.6. The protons of piperazine and morpholine ring showed signals between 3-4.0 ppm. Secondary amine proton comes in the region of $6-7 \mathrm{ppm}$. 


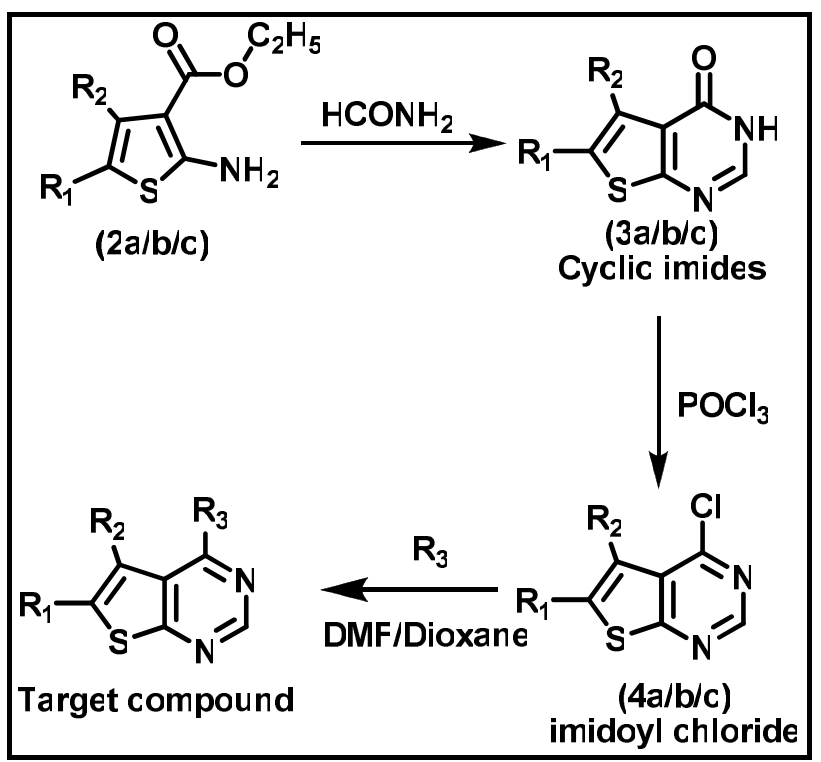

Scheme 1.

Synthesized compounds showed significant decrease in locomotor activity was at dose $20 \mathrm{mg} / \mathrm{kg}$ (Figure 1, 2, 3) and less cataleptic behavior than standard compound at $10 \mathrm{mg} / \mathrm{kg}$ (Figure 4, 5, 6). The compounds were found to be safe after oral administration the dose of $20 \mathrm{mg} / \mathrm{kg}$. No mortality was observed at this dose up to $24 \mathrm{~h}$. There was decrease in alertness, and reactivity to touch stimuli. The animals did not show loss of righting reflex, and body position was normal and no stereotypy and lacrimation was observed.

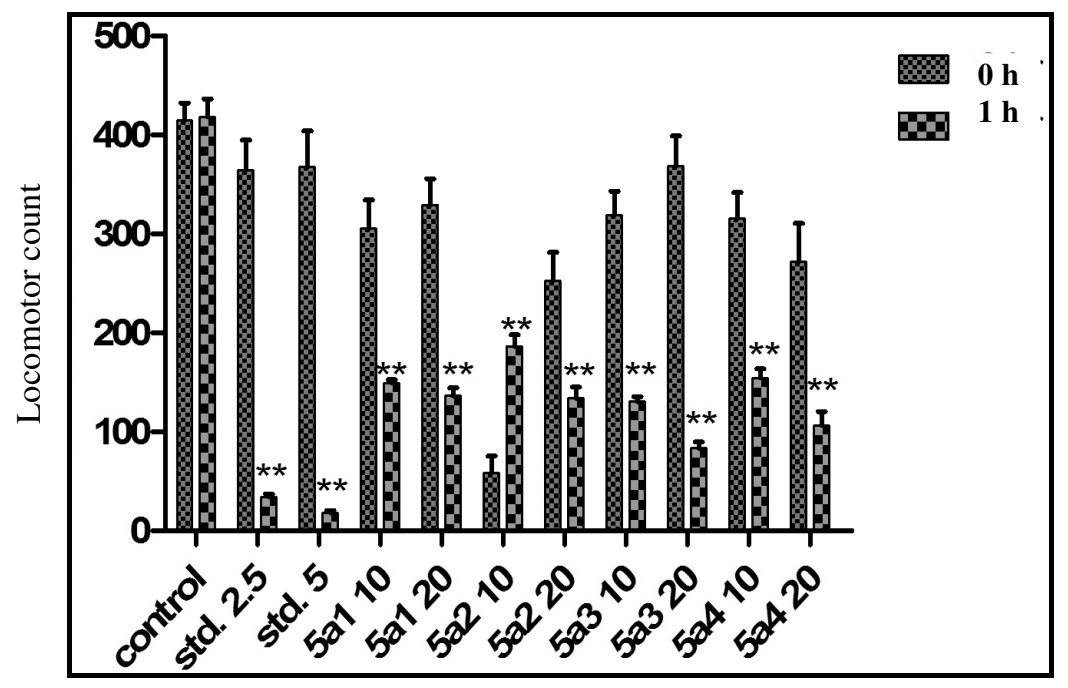

Drug treatment, $\mathrm{mg} / \mathrm{kg}$

Figure 1. Spontaneous motor activity in mice $\left(5 \mathrm{a}_{1}-5 \mathrm{a}_{4}\right)$. 


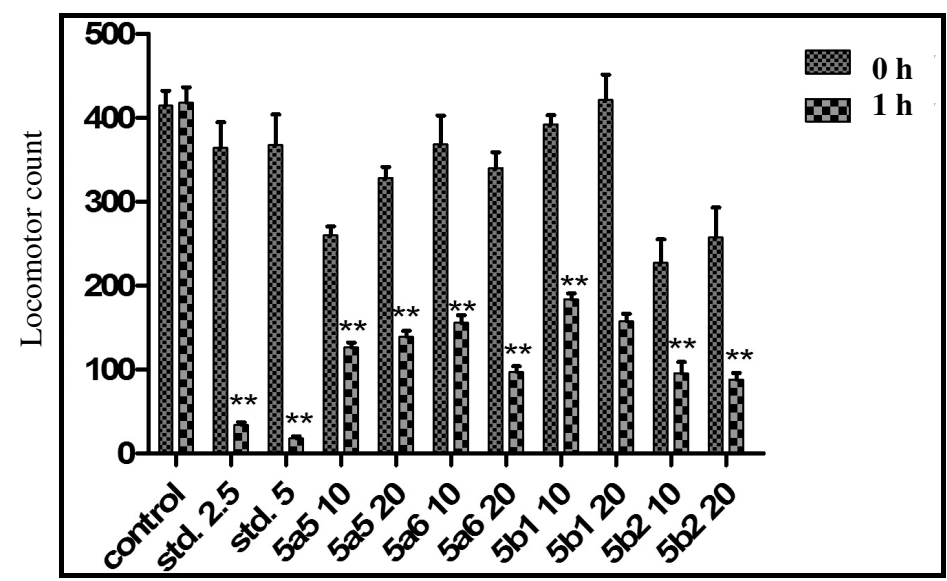

Drug treatment, $\mathrm{mg} / \mathrm{kg}$

Figure 2. Spontaneous motor activity in mice $\left(5 a_{5}-5 b_{2}\right)$.

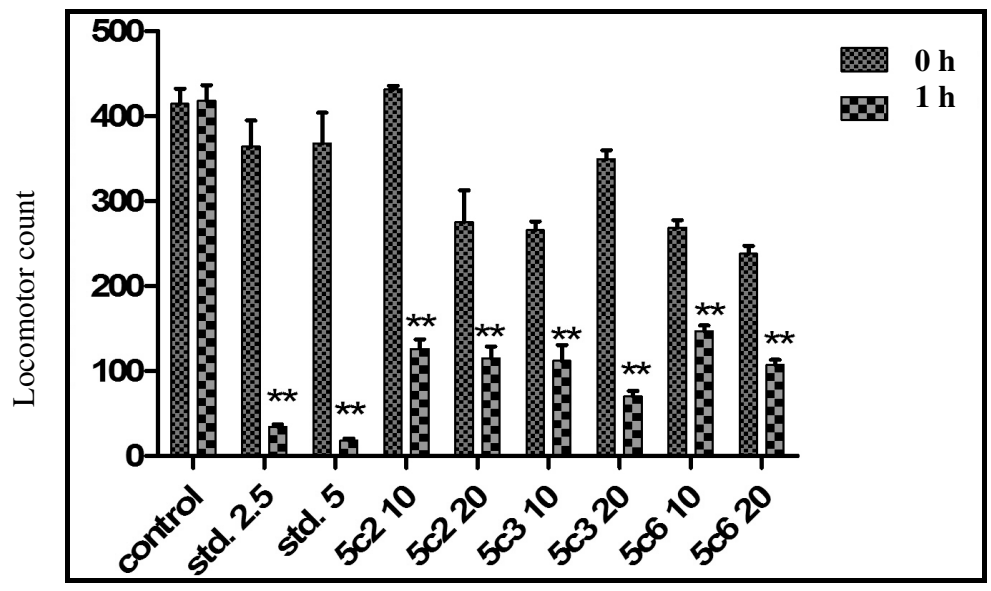

Drug treatment, $\mathrm{mg} / \mathrm{kg}$

Figure 3. Spontaneous motor activity in mice $\left(5 c_{2}-5 c_{6}\right)$

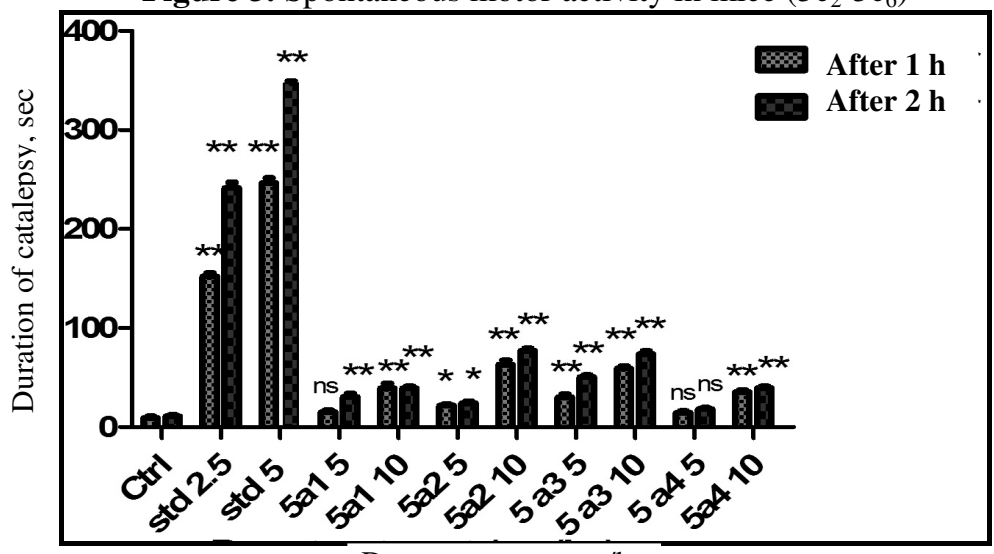

Drug treatment, $\mathrm{mg} / \mathrm{kg}$

Figure 4. Cataleptic behavior in mice $\left(5 \mathrm{a}_{1}-5 \mathrm{a}_{4}\right)$. 


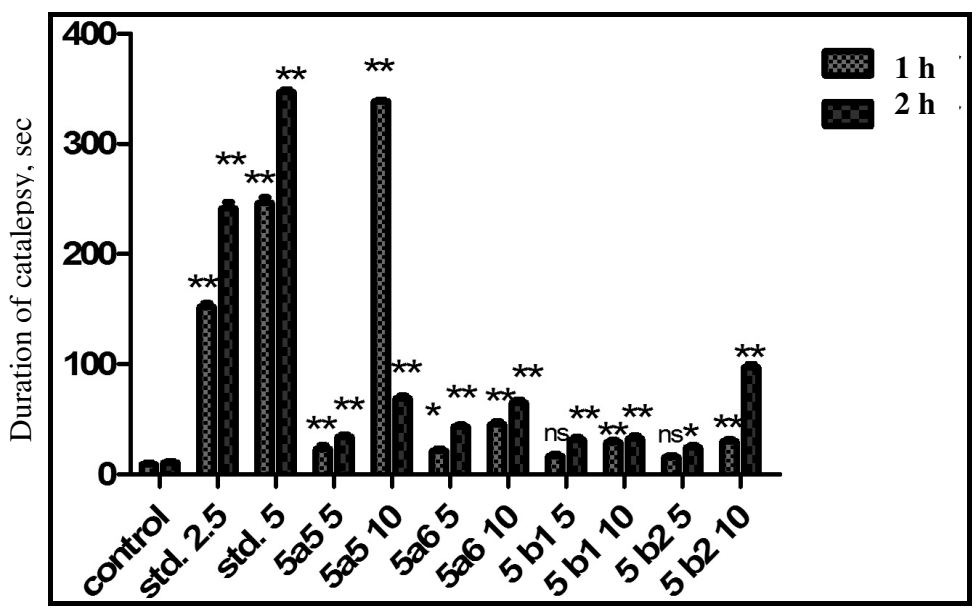

Drug treatment, $\mathrm{mg} / \mathrm{kg}$

Figure 5. Cataleptic behavior in mice $\left(5 \mathrm{a}_{5}-5 \mathrm{~b}_{2}\right)$.

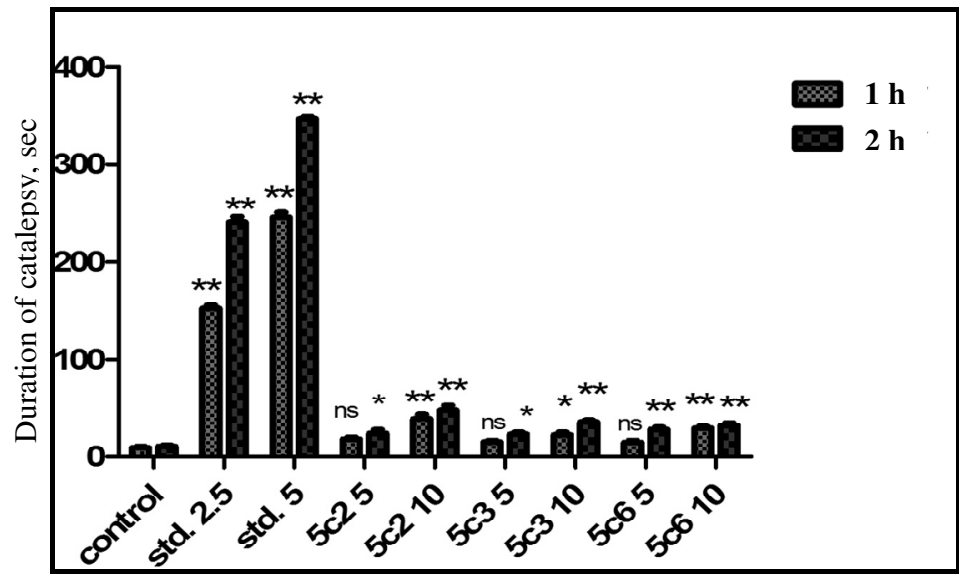

Drug treatment, $\mathrm{mg} / \mathrm{kg}$

Figure 6. Cataleptic behavior in mice $\left(5 c_{2}-5 c_{6}\right)$.

\section{Acknowledgements}

We are thankful to our Principal Dr. Ashok Bhosale for providing us required facilities and motivation for completion of the research work. We also extend our gratitude towards University of Pune for providing us facilities of ${ }^{1} \mathrm{H}$ NMR for characterization of synthesized compounds

\section{References}

1. Meltzer H Y and Stahl S M, Schizophr Bull., 1976, 2, 19-76.

2. Carlsson A, Neuropsychopharmacology, 1988, 1, 179-186.

3. Goldstein, J M, Exp Opin Invest Drugs, 1995, 4, 291-298.

4. Hussenether T, Hubner H M and Gmeiner P, Bioorg Med Chem., 2004, 12, 2625-2637.

5. Borison R L, J Clin Psychopharmacol., 1995, 15, 24-29.

6. Meltzer H Y and McGurk S R, Schizophr Bull., 1999, 25, 233-255. 
7. Gewald K, Angew Chem., 1961, 73, 114.

8. Gewald K, Schinke E and Bottcher H, Chem Ber., 1966, 99, 94-100.

9. Robba M, Lecomte L M and Sevricourt M C, Bull Soc Chim Fr., 1970, 3630.

10. Robba M, Lecomte L M and Sevricourt M C, Bull Soc Chim Fr., 1975, 587.

11. Hesse S, Perspicace E and Kirscl G, Tetrahedron Lett., 2007, 48, 5261-5264.

12. El-Baih F E M, Al- Blowy H A S and Al-Hazimi H M, Molecules, 2006, 11, 498.

13. Shishoo C J, Devani M B, Bhadti V S, Jain K S and Ananthan S, J Heterocyclic Chem., 1990, 27, 119-126.

14. Shishoo C J, Devani M B, Bhadti V S, Jain K S, Ananthan S and Ullas G V, Tetrahedron Lett., 1983, 24, 4611-4612.

15. Achliya G S, Wadodkar S G and Dorle A K, J Ethnopharmacol., 2004, 94, 77-83.

16. Park W K, Jeong D and Cho H, Pharmacol Biochem Behav., 2005, 82, 361-372

17. Irwin S, Taber R I, Fox, J A and Roth F E, Psychopharmacologia, 1968, 12, 441-447. 


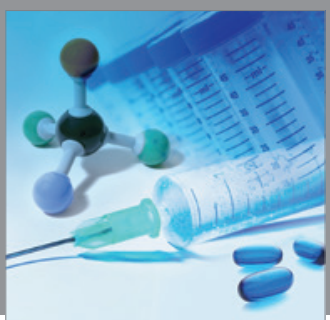

International Journal of

Medicinal Chemistry

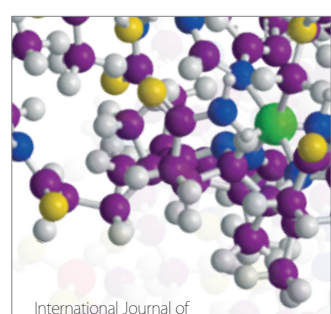

Carbohydrate Chemistry

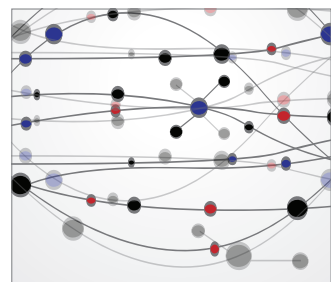

The Scientific World Journal
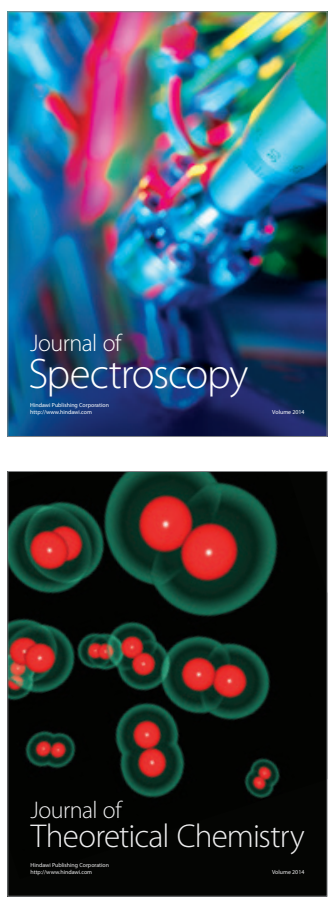
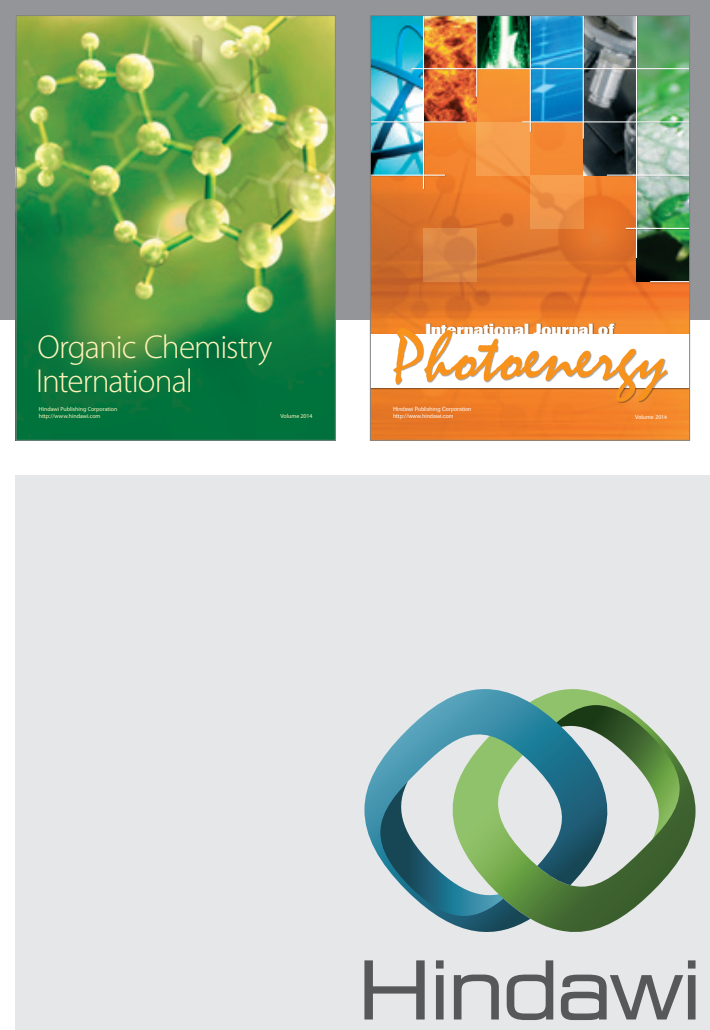

Submit your manuscripts at

http://www.hindawi.com
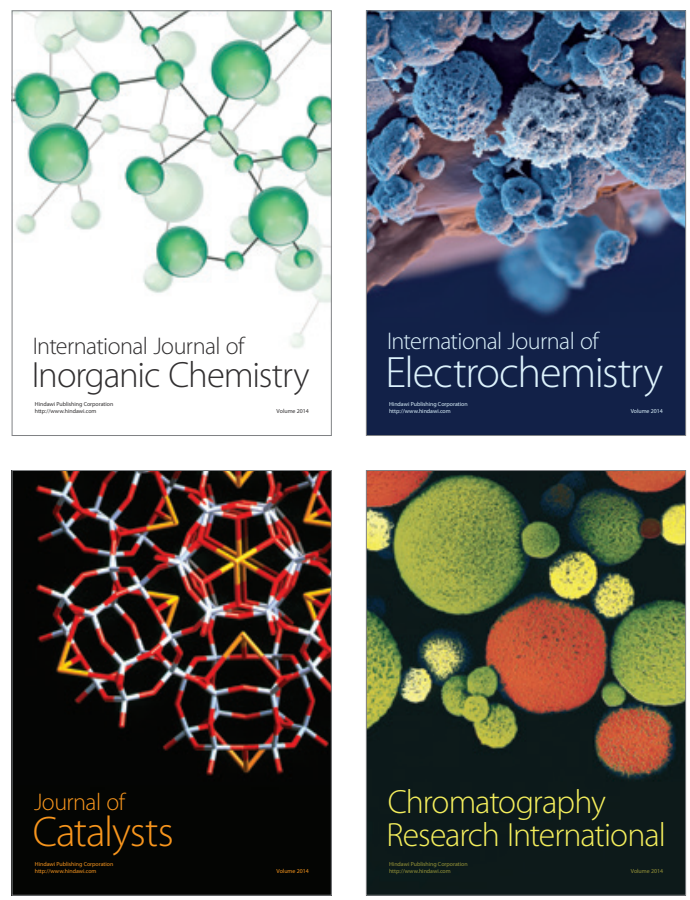
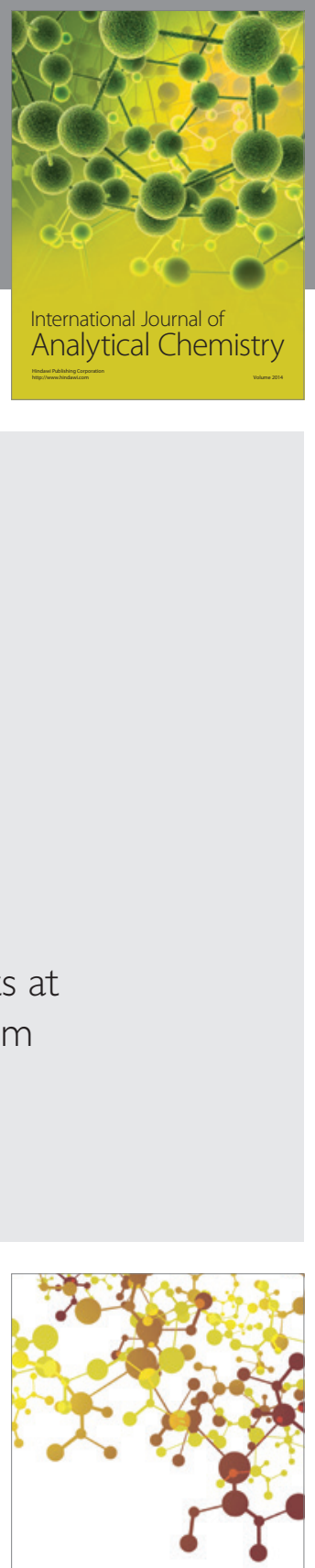

Journal of

Applied Chemistry
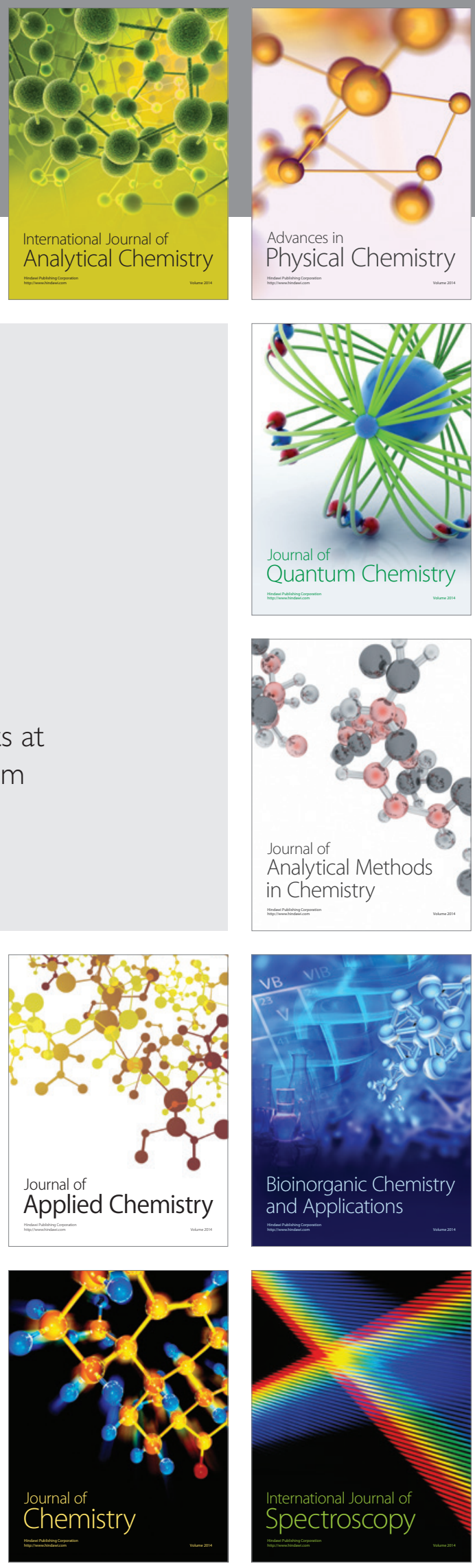